\title{
Simplified approach for analyse of shear walls for multistorey timber buildings
}

\author{
Inese Virbule ${ }^{1}$, Dmitrijs Serdjuks², Karina Buka-Vaivade ${ }^{3}$ \\ Institute of Structural Engineering and Reconstruction, Faculty of Civil Engineering, \\ Riga Technical University, Kipsalas st. 6B/6A, Riga, LV-1048, Latvia
}

E-mail: ${ }^{3}$ Karina.Buka-Vaivade@rtu.lv (corresponding author)

\begin{abstract}
Construction of multi-storey timber buildings represent solution to the global housing shortage which is caused by the increased urbanization and the densification of cities. Three-storey timber building with the platform framing method of major structural member's joining of was considered as an object of investigations. The length and width of considered building were equal to 28 and $13 \mathrm{~m}$, correspondingly. Simplified approach of load-bearing shear wall modelling, which is based on the replacement of the shear wall structure by the lattice structure with the equivalent stiffness, is presented. FEM models were developed by the softwares ANSYS 15.0 and Autodesk Robot Structural for verification of developed simplified approach. It was stated, that the difference between the horizontal displacements obtained for single member of shear wall structure by the developed simplified approach and developed FEM models does not exceeds $5 \%$.
\end{abstract}

Keywords: load-carrying timber members, platform framing, wall panels, horizontal displacements, FEM model.

\section{Introduction}

Development of new timber based structural materials which provide producing of mass structural members enables to delete the limitation on the timber use for the multi-storey buildings. The mass timber structural members are characterized by the increased fire resistance in comparison with the light timber members with the small cross-sections (Green \& Karsh, 2012; Green \& Taggart, 2017; Nedryshkin, Gravit, \& Grabovyy, 2018; Buka-Vaivade, Serdjuks, Goremikins, Pakrastins, \& Vatin, 2018; Saknite, Serdjuks, Goremikins, Pakrastins, \& Vatin, 2016; Schmid, Klippel, Just, Frangi, \& Tiso, 2018). Construction of multi-storey timber buildings represent the most practical, effective and environmentally responsible solution to the global housing shortage which is caused by the increased urbanization and the densification of cities. Timber structures are environmentally friendly. Therefore, replacement of reinforced concrete and steel structures by the timber ones is one of the modern tendencies in civil engineering, which enables to decrease impact on the planet. Production of concrete and steel is responsible for from $5 \%$ to $8 \%$ of global greenhouse gas emissions and requires about $4 \%$ of global energy use. But timber is a renewable and sustainable structural material, trees absorb carbon during growth (Green \& Karsh, 2012; Goremikins, Serdjuks, Buka-Vaivade, Pakrastins, \& Vatin, 2017). The bracing system and shear walls usually provide the spatial stability of the multi-storey timber buildings in case of horizontal actions. Joints between the panels of shear walls have significant influence on the behaviour of multi-storey timber buildings. NMIT Arts and Media Building is a first of multi-storey timber framework buildings, which employs an advanced earthquake design, which enables to avoid the damages (Holden, Devereux, Haydon, Buchanan, \& Pampanin, 2016). Increased stability of the building's structures in case of horizontal actions is provided by the special joints between the panels of shear walls.

Development of the FEM models which enables to take in to account peculiarities of the shear walls joints are necessary for prediction of behaviour of multi-storey timber buildings structures. Simplicity is a very significant parameter of the modelling approaches. It enables to decrease workability and increase effectiveness of the modelling process. Therefore, development of the simplified approach for analyse of shear walls for multi-storey timber building is the aim of current investigation. Three-storey timber building is considered as an object of investigation taking in to account tendency in realisation of the similar objects in Latvia during the last years. 3D model of the considered threestorey timber building, which is developed by the software Autodesk Robot Structural, is shown on Figure 1.

(C) 2019 Authors. Published by VGTU Press. This is an open-access article distributed under the terms of the Creative Commons Attribution (http://creativecommons.org/licenses/by/4.0/) License, which permits unrestricted use, distribution, and reproduction in any medium, provided the original author and source are credited. 


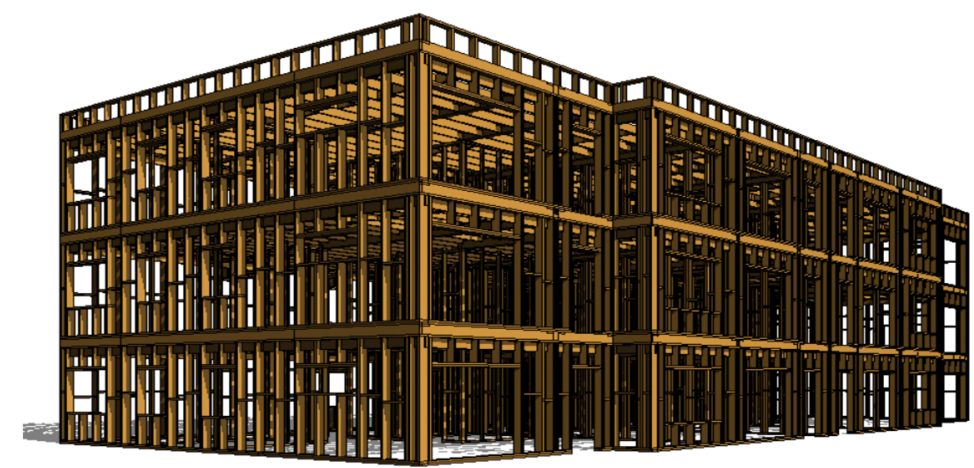

Figure 1. 3D model of the considered three-storey timber building (Virbule, 2015)

Softwares ANSYS 15.0 and Autodesk Robot Structural will be used for the development of the FEM models, which are necessary for the purpose.

\section{Description of object of investigation}

Light framework's structures and platform framing joining method are chosen for the three-storey building which was considered as an object of investigations. Plan and cross-section of considered three-storey building with the structural dimensions are shown on Figure 2.
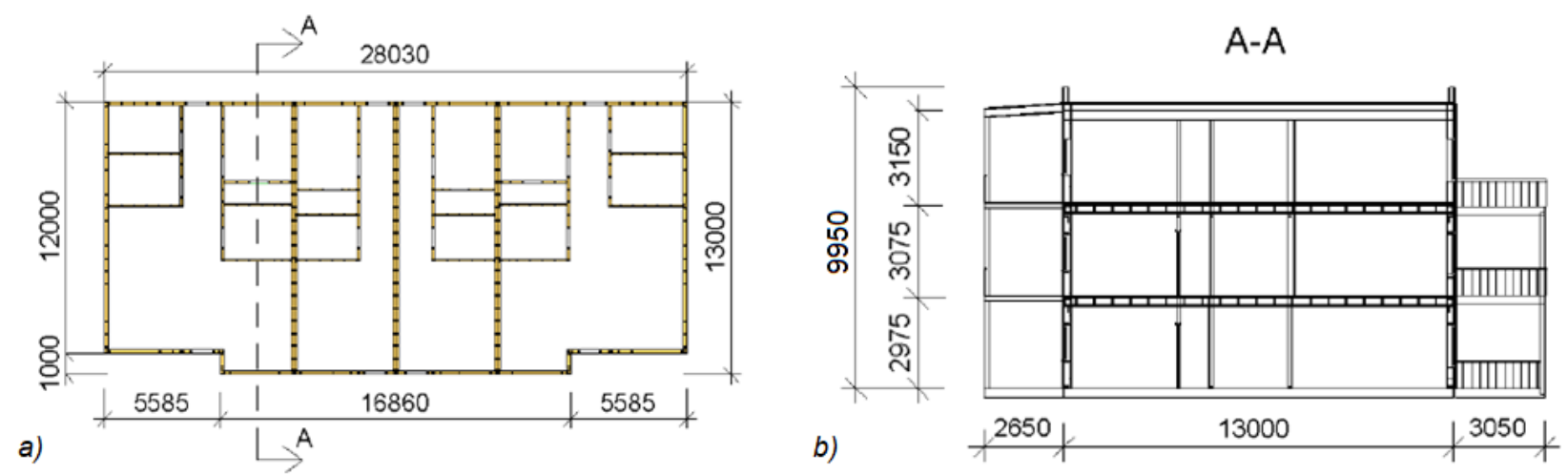

Figure 2. Plan a) and cross-section b) of considered three-storey building (Virbule, 2015)

The platform framing joining method is chosen so as it enables to obtain timber frameworks which are characterized by the increased fire resistance and spatial stability of the framework in comparison with the frameworks obtained by the balloon framing joining method. Decreased length and dead weight of the walls enables to reduce time and cost of the building's erection. The platform framing joining method is considered as a preferable one for the buildings with amounts of the storeys equal or bigger than three (Holden et al., 2016; Virbule, 2015). Structure of the load-bearing shear walls is shown on the Figure 3. Height of the wall's structure is equal to $2.7 \mathrm{~m}$. One row of the cross-bars is placed in the height's middle of the shear wall structure.

This crossing bars provide support of the struts in the middle of its height in plane of the shear walls. Two head binders provide joining of the struts. The struts are placed with the spacings equal to $600 \mathrm{~mm}$ (Virbule, 2015). The depth and width of the struts are equal to 195 and $45 \mathrm{~mm}$, correspondingly. The beams of the roof and floors have solid timber cross-sections with depth and width equal to 220 and $45 \mathrm{~mm}$, correspondingly. Solid timber with strength class C24 was considered as a structural material of timber members (Buchanan, Palermo, Carradine, \& Pampanin, 2011). Birch plywood with mean values of density, flexural modulus of elasticity parallel to the fibres of outer veneers equal to $680 \mathrm{~kg} / \mathrm{m}^{3}$ and $10719 \mathrm{MPa}$, was considered as a material of outer sheets of load-carrying shear walls (EN 338:2016). Thickness of birch plywood sheets was equal to $9 \mathrm{~mm}$. Initial members, panels with height and width equal to 2.7 and $1.2 \mathrm{~m}$, correspondingly, were considered to analyse the load-bearing shear walls of considered three-storey timber building (Virbule, 2015). 

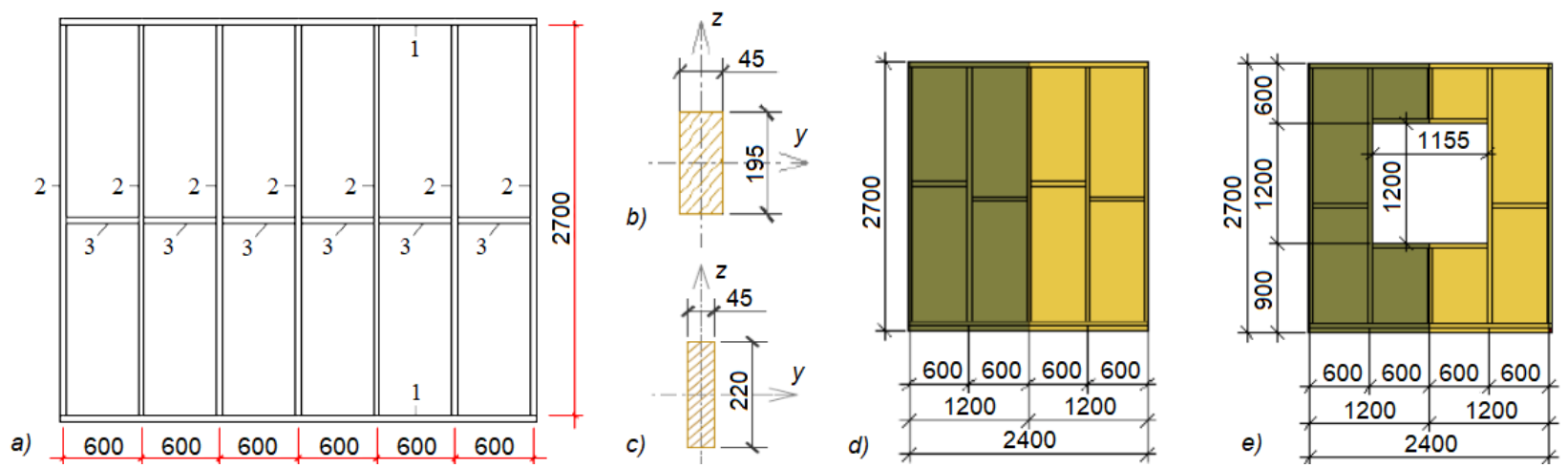

Figure 3. Structure of load-bearing shear walls a): 1 - head binders; 2 - struts; 3 - cross-bars;

b) - cross-section of the struts; c) - cross-section of the beams of roof and floors;

d) - shear wall panel without openings; e) - shear wall panel with window opening (Virbule, 2015)

Two variants of considered shear wall panels: variant without openings and variant with window opening were considered as the objects of investigation.

\section{Simplified approach for analyse of shear walls for multi-storey timber buildings}

\section{Description of FEM models of shear walls}

Existing at the present moment approaches for the finite element modelling of the load-bearing shear walls panels are differed by the consumptions which are taken in to account during the model's development. Load-bearing shear panels consists from the three components, which should be modelled by the different final elements. The components are members of the panel's framework, outer sheets and fasteners. The framework's members usually are modelled by the beam type finite elements. Shall type finite elements are used for the modelling of outer sheets. The fasteners are the most important group of the load-bearing shear wall panel's members which provides interaction of framework's members and outer sheets. Behaviour of the model is dependent from the successful modelling of the fasteners. The fasteners joined together members of framework and outer sheets can be modelled by the spring finite element members. The components of physical and FEM models of load-bearing shear walls panels are shown on the Figure 4 (Ansys Inc., 2013).
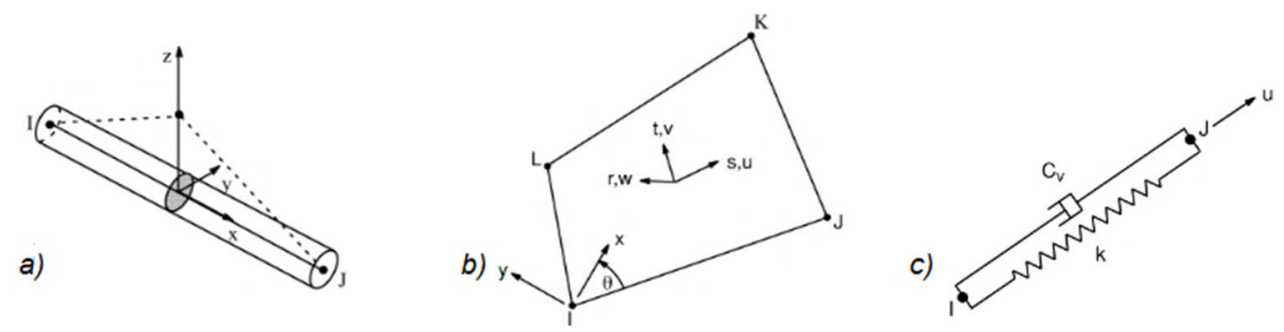

Figure 4. Components of FEM models of load-bearing shear walls panels: a) - final element of the panel's framework; b) - final element of outer sheets; c) - finite element of the fasteners (Ansys Inc., 2013)

The FEM models of load-bearing shear walls panels was developed with the using of software ANSYS 15.0. The finite element's types BEAM 188, SHELL 181 and COMBIN 14 were used for the modelling of the panel's framework, outer sheets and fasteners, correspondingly (Ansys Inc., 2013). The finite elements are shown on the Figure 4 a), b) and c), correspondingly. Solid timber and birch plywood were defined as the orthotropic materials. Slip modulus $\mathrm{K}_{\text {ser }}$ was used to reflect the behaviours of the nails, which were selected as the type of the fasteners used for the considered shear wall panels. Diameter and length of considered nails are equal to 3 and $60 \mathrm{~mm}$, correspondingly. 3D FEM models of the load-bearing wall panels with and without openings are shown on the Figure 5. Elements of the panel's framework have pinned joints in plane $\mathrm{XY}$, but in planes $\mathrm{XZ}$ and $\mathrm{YZ}$ joints of members of framework are restricted (Virbule, 2015). 
a)

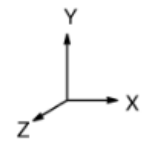

b)

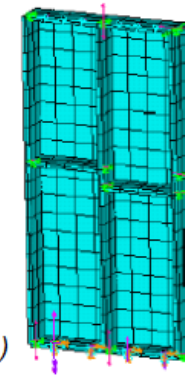

c)

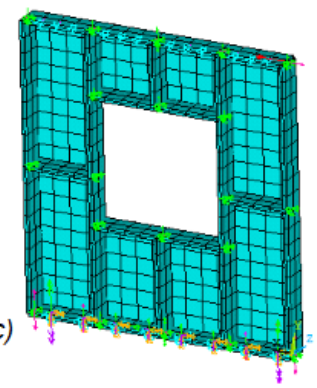

Figure 5. 3D FEM models of the load-bearing wall panels: a) - directions of global coordinate axises system; b) - model of variant without openings; c) - model of variant with the window opening (Virbule, 2015)

The described above FEM models were used for determination of cross-sections of members of considered shear wall panels so as for verification of the simplified approach of load-bearing shear wall analyze, which is described below. Internal forces in the members under the action of the design load combination were determined by the developed in the software ANSYS 15.0 FEM models. Cross-sections of members of considered shear wall panels than was checked by the design methods described in the chapter 6 of Eurocode 1995-1-1 (Porteous \& Kermani, 2007; EN 19951-1:2004+A1:2008). Dimensions of members of considered shear wall panels were mentioned above in the current investigation.

\section{Description of simplified approach for analyse of shear walls}

Simplified approach of load-bearing shear wall analyse is based on the replacement of the shear wall structure by the lattice structure with the equivalent stiffness. Scheme of the lattice structure, used for the shear wall modelling, is shown on Figure 6. Stiffness of the lattice structure, which is equivalent to the stiffness of the modelled load-bearing shear wall, is provided by the corresponding lateral stiffness of the diagonal members $\mathrm{EA}_{2}$, which should be equivalent to the stiffness of corresponding panel.
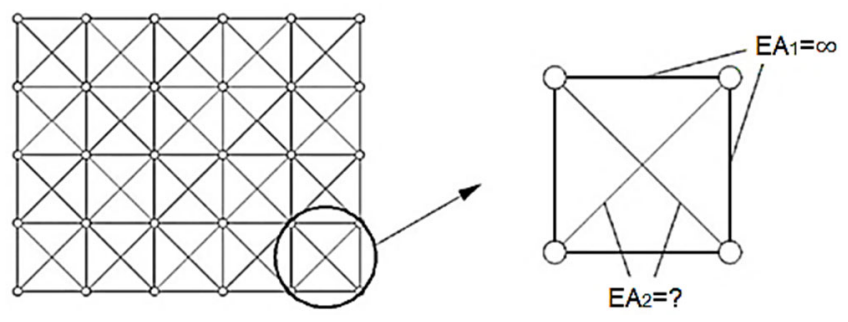

Figure 6. Lattice structure used for the shear wall modelling (Virbule, 2015)

Numerical values of the corresponding lateral stiffness of the diagonal members $\mathrm{EA}_{2}$ should be determined basing on the consumption, that stiffness of the members placed by the contour of a single member is equal to infinity, by the Eq. (1):

$$
1 \cdot u=\sum_{n=1}^{2 n_{t}} \frac{\overline{N_{n}} N_{n} L_{t}}{E A_{t}}=\left(2 n_{t}\right) \cdot \frac{\left(\frac{1}{2 n_{t} \sin \theta}\right) \cdot\left(\frac{F}{2 n_{t} \sin \theta}\right) \cdot\left(\frac{d}{\cos \theta}\right)}{E A_{t}},
$$

where: $u$ - horizontal displacements of single member of the lattice structure; $L_{t}-$ length of the diagonal members; $E$ - elasticity modulus of diagonal members; $A_{t}$ - cross-sectional area of the diagonal members; $n_{t}$ - amount of members in the considered lattice structure; $\overline{N_{n}}$ - axial force in the diagonal member from the single force; $N_{n}$ - axial force in the diagonal member from the external force; $\theta$ - angle between the diagonals of single member in deformed and nondeformed positions.

The angle between the diagonals of single member of the lattice structure in deformed and non-deformed positions should be determined by the Eq. (2) basing on the scheme, which is shown on the Figure 7.

$$
\sin \theta=\frac{a}{\sqrt{a^{2}+d^{2}}},
$$

where: $a$ - width of single member of the lattice structure; $d$ - height of single member of the lattice structure. 
Deformation of the single member of the lattice structure under the action of external horizontal force is shown on the Figure 7.

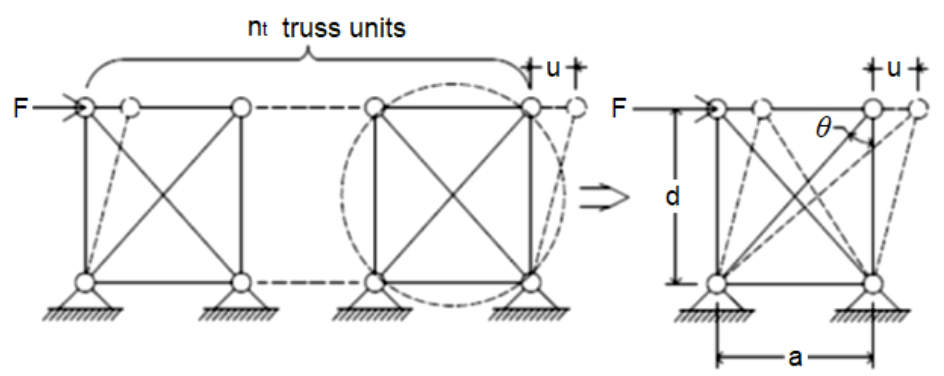

Figure 7. Deformation of single member of the lattice structure under the action of external horizontal force:

$\mathrm{F}$ - external horizontal force; $\mathrm{u}$ - horizontal displacements of single member of the lattice structure;

$\mathrm{a}$ - width of single member of the lattice structure; $d$ - height of single member of the lattice structure;

$\theta$ - angle between the diagonals of single member in deformed and non-deformed positions (Virbule, 2015) Eq. (3).

The horizontal displacements of single member of the lattice structure should be determined by the using of

$$
K_{s}=\frac{F}{u},
$$

where: $K_{s}$ - stiffness of the modelled load-bearing shear wall; other designations are as for Eq. (1).

Necessary cross-sectional area of the diagonal members $A_{t}$ should be determined by the Eq. (4), which is obtained on the base of Eqs (1)-(3).

$$
A_{t}=\frac{K_{s} \cdot\left(a^{2}+d^{2}\right)^{\frac{2}{3}}}{2 n_{t} a^{2} E},
$$

where designations are as for Eqs (1)-(3).

Numerical realization of the considered simplified approach for analyse of shear walls for multi-storey timber buildings is presented for the case, when the building is subjected to the action of the horizontal (wind) load acting perpendicular to the longitudinal load-bearing wall of considered three-storey timber building.

\section{Numerical results}

Scheme of the horizontal (wind) load application to the longitudinal load-bearing wall of considered three-storey timber building so as designation of shear walls is shown on the Figure 8. The building is divided by the shear walls into four sections. Three couples of shear walls S2 and S3, S4 and S5, S6 and S7 develop three internal diaphragms.

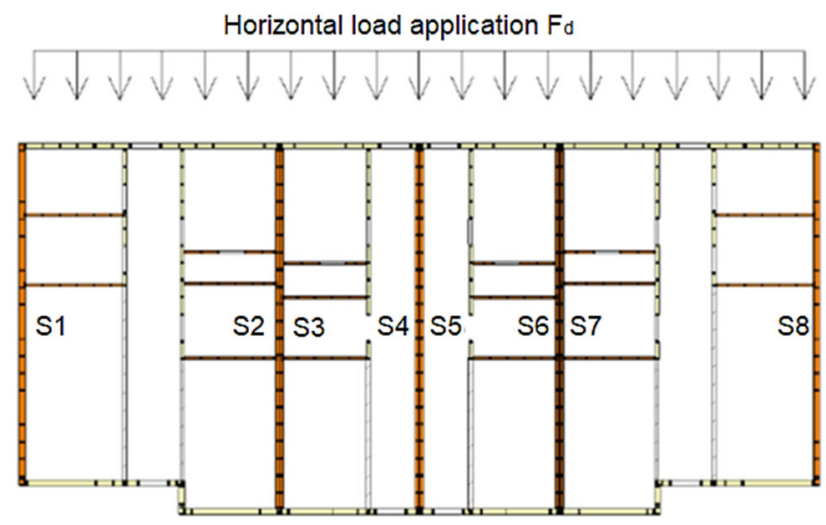

Figure 8. Scheme of the horizontal (wind) load application to the longitudinal load-bearing wall of considered three-storey timber building: S1 - S8 designation of shear walls of considered building (Virbule, 2015)

Structure of one storey of load-bearing shear wall S-1 is presented in Figure 9. It was formed by the panels S1-1, S1-2, S1-3 and S1-4. Height of the structure $\mathrm{H}_{\mathrm{s}}$ is equal to $2.7 \mathrm{~m}$. 


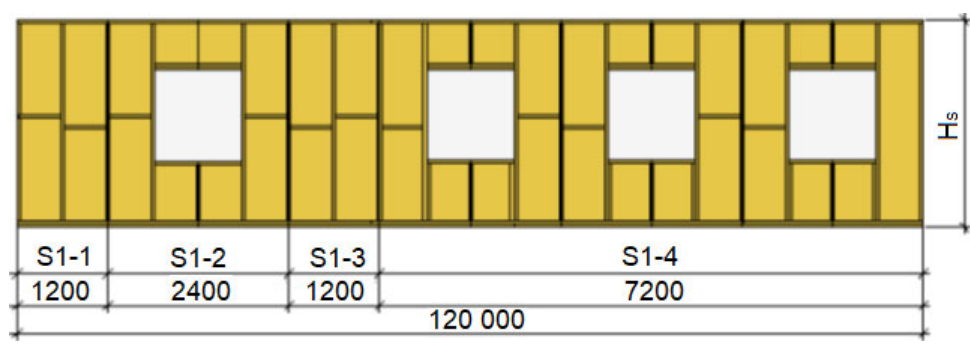

Figure 9. Structure of one storey of load-bearing shear wall S-1 (Virbule, 2015)

Two types of the lattice units were used for the modelling of the panels. Lattice unit A-1 was used for the modelling of the panels S1-1 and S1-3. Lattice unit A-2 was used for the modelling of the panels S1-2 and S1-4. Scheme of the lattice structure for the modelling of one-storey of load-bearing shear wall S-1 is shown on the Figure 10.

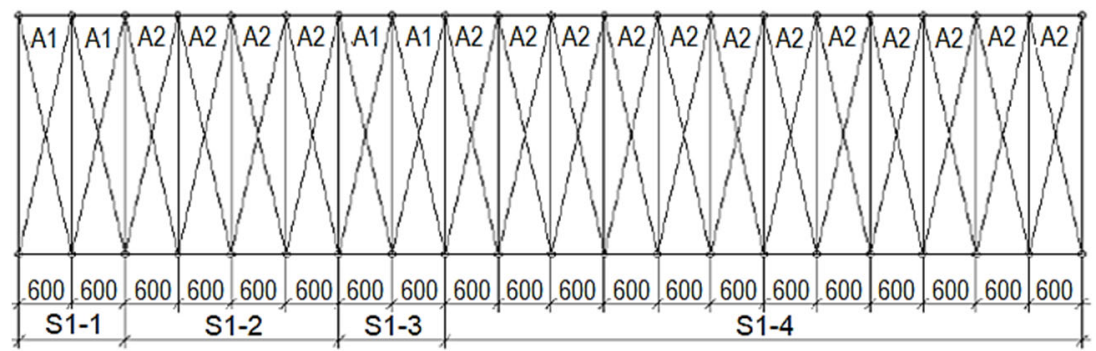

Figure 10. Scheme of the lattice structure for the modelling of one-storey of load-bearing shear wall S-1 (Virbule, 2015)

Three-storey timber building is considered under the action of permanent and imposed load, determined as for the residential building, and snow and wind loads determined for Riga climatic conditions (Vebsy, 2008; EN 1991-11:2002+AC:2009). Intensity of design permanent loads acting on the roof and floors are equal to 1.30 and $1.80 \mathrm{kPa}$. Intensity of characteristic value of imposed load was taken as $2.0 \mathrm{kPa}$. Design snow load acting on the roof was equal to $2.04 \mathrm{kPa}$. The maximum values of positive and negative wind pressure are equal to 0.77 and $1.14 \mathrm{kPa}(\mathrm{EN} 1991-1-$ 1:2002+AC:2009). A $A_{t}$ were determined for the shear walls S1 - S8 by the Eqs (1)-(4) and are summarized in the Table 1.

Table 1. Necessary cross-sectional areas At of the diagonal members of shear walls models

\begin{tabular}{|c|c|c|c|c|c|c|c|c|}
\hline Wall Nr. & Lsi $(\mathrm{mm})$ & $\mathrm{a}(\mathrm{mm})$ & $\mathrm{Hs}(\mathrm{mm})$ & $\mathrm{d}(\mathrm{mm})$ & $\mathrm{Ks}(\mathrm{N} / \mathrm{mm})$ & $\mathrm{nt}$ & $\mathrm{E}(\mathrm{MPa})$ & $\mathrm{At}\left(\mathrm{mm}^{2}\right)$ \\
\hline S1-1 & 2400 & 600 & 2700 & 2700 & 668.74 & 4 & 11000 & 446.65 \\
\hline S1-2 & 2400 & 600 & 2700 & 2700 & 453.00 & 4 & 11000 & 302.56 \\
\hline S1-3 & 1200 & 600 & 2700 & 2700 & 334.37 & 2 & 11000 & 446.65 \\
\hline S1-4 & 7200 & 600 & 2700 & 2700 & 1359.00 & 12 & 11000 & 302.56 \\
\hline S2 & 13000 & 1200 & 2700 & 2700 & 3616.70 & 10 & 11000 & 294.48 \\
\hline S3 & 13000 & 1200 & 2700 & 2700 & 3598.50 & 10 & 11000 & 292.99 \\
\hline S4 & 13000 & 1200 & 2700 & 2700 & 3598.50 & 10 & 11000 & 292.99 \\
\hline S5 & 13000 & 1200 & 2700 & 2700 & 3598.50 & 10 & 11000 & 292.99 \\
\hline S6 & 13000 & 1200 & 2700 & 2700 & 3598.50 & 10 & 11000 & 292.99 \\
\hline S7 & 13000 & 1200 & 2700 & 2700 & 3616.70 & 10 & 11000 & 294.48 \\
\hline S8-1 & 2400 & 600 & 2700 & 2700 & 668.74 & 4 & 11000 & 446.65 \\
\hline S8-2 & 2400 & 600 & 2700 & 2700 & 453.00 & 4 & 11000 & 302.56 \\
\hline S8-3 & 1200 & 600 & 2700 & 2700 & 334.37 & 2 & 11000 & 446.65 \\
\hline S8-4 & 7200 & 600 & 2700 & 2700 & 1359.00 & 12 & 11000 & 302.56 \\
\hline
\end{tabular}

The values of $A_{t}$ for the internal shear walls $S 2-S 7$ are practically constant and changes within the limits from 292.99 to $294.48 \mathrm{~mm}^{2}$. The values of $A_{t}$ for the external shear walls S1 and S2 are practically constant and changes within the limits from 302.56 to $446.65 \mathrm{~mm}^{2}$. The values of horizontal displacements of single member of the lattice structure obtained by the simplified approach under the action of load combination including dead weight and wind 
load were compared with the results obtained by the FEM model created by the software ANSYS 15 . The differences were equal to 0.11 and $4.06 \%$ for the wall panels without openings and with window opening, correspondingly. The considered panels were S1-1 and S 1-2, which are shown on the Figure 9. 3D FEM model of light framework structure of three-storey timber building (Figure 11) was created by the software Autodesk Robot Structural for verification of the simplified approach for analyse of shear walls. The model was created with the using of lattice units A-1 and A-2. The model was analysed under the same loads action as it was mentioned above for the analyse by the simplified approach.
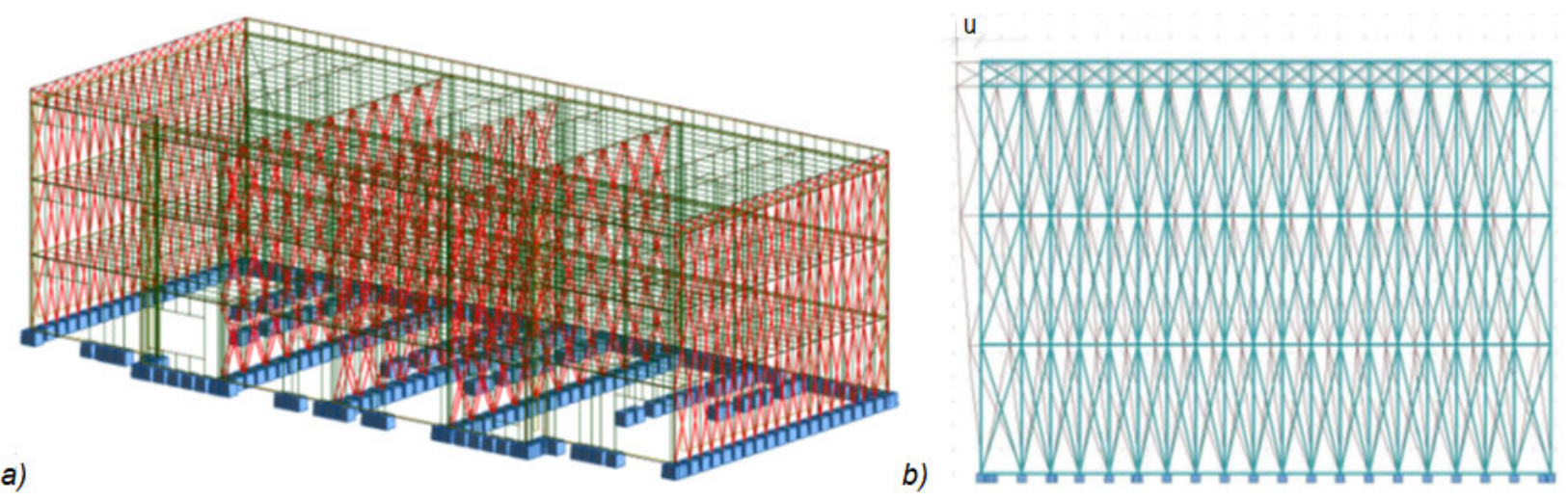

Figure 11. Model of light framework structure of three-storey timber building created by the software Autodesk Robot Structural: a) - 3D model; b) - deformed shape of external shear walls S1 and S8 (Virbule, 2015)

The maximum horizontal displacements were obtained for the external shear walls S1 and S8. The value of maximum horizontal displacement is equal to $8.50 \mathrm{~mm}$, what is 1.91 times less, than the maximum available value (Virbule, 2015). The values of horizontal displacements of single member of the lattice structure obtained by the simplified approach and by the 3D FEM model which was created by the software Autodesk Robot Structural were compared. It was stated, that the difference does not exceeds 5\%. So, it can be concluded, that the simplified approach of loadbearing shear wall's analyse, which is based on the replacement of the shear wall structure by the lattice structure with the equivalent stiffness, enables to predict behaviour of shear wall panels with enough precision (Virbule, 2015).

\section{Conclusions}

Simplified approach of load-bearing shear wall's analyse which is based on the replacement of the shear wall structure by the lattice structure with the equivalent stiffness was developed. The possibility of the simplified approach using for the behaviour prediction of shear walls for multi-storey timber buildings was checked on the example of threestorey timber building with load-bearing shear walls.

FEM models were developed by the softwares ANSYS 15.0 and Autodesk Robot Structural for verification of developed simplified approach. It was stated, that the difference between the horizontal displacements obtained for single member of shear wall structure by the developed simplified approach and developed FEM models does not exceeds $5 \%$. So, it was shown, that the simplified approach of load-bearing shear wall's analyse is characterized by simplicity of design procedure and reasonable precision in comparison with FEM modelling.

\section{Acknowledgements}

This work was supported by Riga Technical University, Faculty of Building and Civil Engineering Grant [grant number DOK.BIF/18].

\section{References}

Ansys Inc. (2013). ANSYS 15.0 ANSYS Fluent User's Guide. Retrieved from http://www.sylvain-serra.fr/res/fluent tuto.pdf

Buchanan, A., Palermo, A., Carradine, D. M., \& Pampanin, S. (2011). Post-tensioned timber frame buildings. The Structural Engineer, 89(17), 24-30.

Buka-Vaivade, K., Serdjuks, D., Goremikins, V., Pakrastins, L., \& Vatin, N. I. (2018). Suspension structure with cross-laminated timber deck panels. Magazine of Civil Engineering, 83(7), 126-135. https://doi.org/10.18720/MCE.83.12

European Committee for Standartization. (2008). Eurocode 5: Design of timber structures - Part 1-1: General - Common rules and rules for buildings (EN 1995-1-1:2004+A1:2008). 
Virbule, I.; Serdjuks, D.; Buka-Vaivade, K. 2019. Simplified approach for analyse of shear walls for multistorey timber buildings

European Committee for Standartization. (2009). Eurocode 1: Actions on structures - Part 1-1: General actions - Densities, selfweight, imposed loads for buildings (EN 1991-1-1:2002+AC:2009).

European Committee for Standartization. (2016). Structural timber. Strength classes (EN 338:2016).

Goremikins, V., Serdjuks, D., Buka-Vaivade, K., Pakrastins, L., \& Vatin, N. I. (2017). Prediction of behaviour of prestressed suspension bridge with timber deck panels. The Baltic Journal of Road and Bridge Engineering, 12(4), 234-240. https://doi.org/10.3846/bjrbe.2017.29

Green, M., \& Karsh, E. (2012). The case for tall wood buildings. Vancouver: MGB.

Green, M., \& Taggart, J. (2017) Tall wood buildings design, construction and performance. Basel: Birkhauser. https://doi.org/10.1080/24751448.2018.1497379

Holden, T., Devereux, C., Haydon, S., Buchanan, A., \& Pampanin, S. (2016). NMIT arts and media building - Innovative structural design of a three-storey post-tensioned timber building. Case Studies in Structural Engineering, 6, 76-83. https://doi.org/10.1016/j.csse.2016.06.003

Nedryshkin, O., Gravit, M., \& Grabovyy, K. (2018). Modeling fires in structures with an atrium in the FDS field model. MATEC Web of Conferences, 193, 03023. https://doi.org/10.1051/matecconf/201819303023

Porteous, J., \& Kermani, A. (2007). Structural timber design to Eurocode 5. Malden, MA: Blackwell Publishing Ltd. https://doi.org/10.1002/9780470697818

Saknite, T., Serdjuks, D., Goremikins, V., Pakrastins, L., \& Vatin, N. I. (2016). Fire design of arch-type timber roof. Magazine of Civil Engineering, 64(4), 26-39. https://doi.org/10.5862/MCE.64.3

Schmid, J., Klippel, M., Just, A., Frangi, A., \& Tiso, M. (2018). Simulation of the Fire Resistance of Cross-laminated Timber (CLT). Fire Technology, 54(5), 1113-1148. https://doi.org/10.1007/s10694-018-0728-9

Vebsy, J. (2008). Shear walls for multi-storey timber buildings. Växjö: School of Technology and Design, Växjö University.

Virbule, I. (2015). Behavioural analysis of load-carrying elements of three-storey timber framework building (M.S. thesis). Riga: Riga Technical university. 